\title{
Endogenous $\mathrm{Ca}^{2+}$ Buffer Concentration and $\mathrm{Ca}^{2+}$ Microdomains in Hippocampal Neurons
}

\author{
Andreas Müller, ${ }^{1}$ Maria Kukley, ${ }^{1}$ Pia Stausberg, ${ }^{1}$ Heinz Beck, ${ }^{2}$ Wolfgang Müller, ${ }^{3}$ and Dirk Dietrich ${ }^{1}$ \\ Departments of ${ }^{1}$ Neurosurgery and ${ }^{2}$ Epileptology, University Clinic Bonn, D-53105 Bonn, Germany, and ${ }^{3}$ Charite, Neurowissenschaftliches \\ Forschungszentrum, D-10117 Berlin, Germany
}

$\mathrm{Ca}^{2+}$-binding proteins are ubiquitously expressed throughout the CNS and serve as valuable immunohistochemical markers for certain types of neurons. However, the functional role of most $\mathrm{Ca}^{2+}$-binding proteins has to date remained obscure because their concentration in central neurons is not known. In this study, we investigate the intracellular concentration of the widely expressed $\mathrm{Ca}^{2+}$-binding protein calbindin- $\mathrm{D}_{28 \mathrm{k}}$ in adult hippocampal slices using patch-clamp recordings and immunohistochemistry. First, we show that calbindin- $\mathrm{D}_{28 \mathrm{k}}$ freely exchanges between patch pipette and cytoplasm during whole cell patch-clamp recordings with a time constant of $\sim 10 \mathrm{~min}$. Substituting known concentrations of recombinant calbindin- $\mathrm{D}_{28 \mathrm{k}}$ in patch pipettes enabled us to determine the endogenous calbindin- $\mathrm{D}_{28 \mathrm{k}}$ concentration by postrecording immunohistochemistry. Using this calibration procedure, we find that mature granule cells (doublecortin - ) contain $\sim 40 \mu \mathrm{M}$, and newborn granule cells (doublecortin + ) contain $0-20 \mu \mathrm{M}$ calbindin- $\mathrm{D}_{28 \mathrm{k}}$. CA3 stratum radiatum interneurons and CA1 pyramidal cells enclose $\sim 47$ and $\sim 45 \mu \mathrm{M}$ calbindin- $\mathrm{D}_{28 \mathrm{k}}$, respectively. Numerical simulations showed that $40 \mu \mathrm{M}$ calbindin- $\mathrm{D}_{28 \mathrm{k}}$ is capable of tuning $\mathrm{Ca}^{2+}$ microdomains associated with action potentials at the mouth of single or clustered $\mathrm{Ca}^{2+}$ channels: calbindin- $\mathrm{D}_{28 \mathrm{k}}$ reduces the increment in free $\mathrm{Ca}^{2+}$ at a distance of 100 and $200 \mathrm{~nm}$ by 20 and $35 \%$, respectively, and strongly accelerates the collapse of the $\mathrm{Ca}^{2+}$ gradient after cessation of $\mathrm{Ca}^{2+}$ influx. These data suggest that calbindin- $\mathrm{D}_{28 \mathrm{k}}$ equips hippocampal neurons with $\sim 160 \mu \mathrm{m}$ mobile, high-affinity $\mathrm{Ca}^{2+}$-binding sites $\left(\kappa_{\mathrm{S}} \sim 200\right)$ that slow and reduce global $\mathrm{Ca}^{2+}$ signals while they enhance the spatiotemporal fidelity of submicroscopic $\mathrm{Ca}^{2+}$ signals.

Key words: calcium; calcium binding ratio; adult neurogenesis; confocal laser scanning microscopy; buffered calcium diffusion; single compartment model

\begin{abstract}
Introduction
$\mathrm{Ca}^{2+}$ is a highly versatile intracellular signal known to be important in a wide range of cellular functions such as excitability, transmitter release, gene transcription, or neuronal cell death. How the spatial and temporal extent of a rise in intracellular $\mathrm{Ca}^{2+}$ is shaped is therefore a fundamental question. A key factor in determining the spatiotemporal dynamics of $\mathrm{Ca}^{2+}$ signals is the presence of mobile endogenous $\mathrm{Ca}^{2+}$ buffers in the cytosol. Intracellular $\mathrm{Ca}^{2+}$ signals may be differentially affected by the presence of mobile $\mathrm{Ca}^{2+}$ buffers, depending on the spatial dimension of the signal (for review, see Neher, 1998). Global $\mathrm{Ca}^{2+}$ signals that encompass a large portion of neuronal compartments, such as dendritic $\mathrm{Ca}^{2+}$ signals associated with backpropagating action potentials, will be slowed and their initial amplitude will be decreased. More restricted $\mathrm{Ca}^{2+}$ signals, such as those occurring in spines or dendritic subsegments, can have an enlarged range of action: by competing with fixed cytosolic
\end{abstract}

\footnotetext{
Received Sept. 14, 2004; revised Nov. 18, 2004; accepted Nov. 22, 2004.

This work was supported by the Deutsche Forschungsgemeinschaft (SFB TR3, GK 246, and Mu809/6 -3), University Clinic Bonn grants (BONFOR), and the Gertrud-Reemtsma-Stiftung of the Max-Planck-Gesellschaft.

Correspondence should be addressed to Dr. Dirk Dietrich, Department of Neurosurgery, NCH U1 R035, Experimental Neurophysiology, University Clinic Bonn, Sigmund-Freud Strasse 25, D-53105 Bonn, Germany. E-mail: dirk.dietrich@ukb.uni-bonn.de.

DOI:10.1523/JNEUROSCI.3799-04.2005

Copyright $\odot 2005$ Society for Neuroscience $\quad$ 0270-6474/05/250558-08\$15.00/0
}

$\mathrm{Ca}^{2+}$-binding sites, diffusible buffers are capable of enhancing $\mathrm{Ca}^{2+}$ diffusion and thus counteract the compartmentalization of $\mathrm{Ca}^{2+}$ signals. At the scale of the highly localized $\mathrm{Ca}^{2+}$ build-up in the vicinity of single $\mathrm{Ca}^{2+}$-permeable channels (so-called $\mathrm{Ca}^{2+} \mathrm{mi}-$ crodomains), $\mathrm{Ca}^{2+}$ transients will be spatially and temporally restricted by the presence of mobile buffers. How the different types of $\mathrm{Ca}^{2+}$ signals are modified depends critically on the $\mathrm{Ca}^{2+}$-binding properties and the intracellular concentration of the buffer. For example, whereas low micromolar concentrations of high-affinity $\mathrm{Ca}^{2+}$ buffers strongly affect global $\mathrm{Ca}^{2+}$ transients (Helmchen et al., 1996) as well as the diffusional spread of $\mathrm{Ca}^{2+}$ (Gabso et al., 1997), high concentrations and fast binding rates of mobile buffers are needed to affect microdomain $\mathrm{Ca}^{2+}$ signaling (Roberts, 1994).

A major endogenous $\mathrm{Ca}^{2+}$ buffer is the $\mathrm{Ca}^{2+}$-binding protein calbindin- $\mathrm{D}_{28 \mathrm{k}}$, which is prominently expressed in specific types of neurons throughout the CNS, including hippocampal granule and pyramidal cells as well as cerebellar Purkinje cells (Baimbridge et al., 1992). Calbindin- $\mathrm{D}_{28 \mathrm{k}}$ is the primary $\mathrm{Ca}^{2+}$-binding protein of hippocampal principal cells, because they do not contain other $\mathrm{Ca}^{2+}$-binding proteins such as parvalbumin or calretinin. Calbindin- $\mathrm{D}_{28 \mathrm{k}}$ belongs to the EF-hand family of $\mathrm{Ca}^{2+}$ binding proteins and contains four high-affinity $\mathrm{Ca}^{2+}$-binding sites (Veenstra et al., 1997; Berggard et al., 2002) that bind $\mathrm{Ca}^{2+}$ with a fast association rate (Nägerl et al., 2000). Attempts have been made to estimate the endogenous buffer concentration in 
calbindin- $\mathrm{D}_{28 \mathrm{k}}$-containing neurons using microfluorometric imaging techniques and quantitative analysis of $\mathrm{Ca}^{2+}$ signaling (Maeda et al., 1999; Jackson and Redman, 2003). However, these studies used models that depend on several parameters that are not known and only speculate about the molecular identity of the underlying buffers. Therefore, the intracellular concentration of calbindin- $\mathrm{D}_{28 \mathrm{k}}$ has remained unclear to date, and the role of this $\mathrm{Ca}^{2+}$-binding protein in shaping the spatiotemporal dynamics of intracellular $\mathrm{Ca}^{2+}$ signals is still difficult to judge.

In this study, we use a novel approach combining patchclamp recordings with intracellular dialysis of purified calbindin- $\mathrm{D}_{28 \mathrm{k}}$ and postrecording immunohistochemistry to quantitatively determine the intraneuronal concentration of calbindin- $\mathrm{D}_{28 \mathrm{k}}$ in hippocampal neurons.

\section{Materials and Methods}

Preparation of slices and recording configuration. Wistar rats or adult mice (20- to 40-d-old) (see below) were decapitated under ether anesthesia. The brain was rapidly dissected and chilled in $4^{\circ} \mathrm{C}$ cold cutting solution consisting of (in mM): $140 \mathrm{NaCl}, 3 \mathrm{KCl}, 2 \mathrm{MgSO}_{4}, 2 \mathrm{CaCl}_{2}, 1 \mathrm{Na}$ pyruvate, 10 HEPES, and 10 glucose, pH $7.4\left(\mathrm{NaOH}, 100 \% \mathrm{O}_{2}\right)$. Four hundred micrometer horizontal hippocampal slices were prepared with a vibratome (Leica, Nussloch, Germany). For recording, slices were transferred to an interface chamber perfused with $\operatorname{ACSF}\left(35 \pm 0.5^{\circ} \mathrm{C}\right)$ that contained (in mM): $125 \mathrm{NaCl}, 3 \mathrm{KCl}, 2 \mathrm{CaCl}_{2}, 2 \mathrm{MgCl}_{2}, 1.25 \mathrm{NaH}_{2} \mathrm{PO}_{4}$, $20.3 \mathrm{NaHCO}_{3}$, and 12 D-glucose, pH $7.4\left(95 \% \mathrm{O}_{2}\right.$ and $\left.5 \% \mathrm{CO}_{2}\right)$. Patch pipettes had resistances between 4 and $5 \mathrm{M} \Omega$. The standard pipette solution was free of any $\mathrm{Ca}^{2+}$ chelators and contained (in $\mathrm{mM}$ ): $140 \mathrm{~K}^{+}$. gluconate, $0.5 \mathrm{MgCl}_{2}, 4 \mathrm{NaCl}, 10 \mathrm{HEPES}, 5 \mathrm{KCl}$, and $0.1 \%$ Lucifer yellow (LY). A small amount of EGTA $(20 \mu \mathrm{M})$ was added to the solution to balance $\mathrm{Ca}^{2+}$ contamination of salts.

A $100 \mu \mathrm{M}$ calbindin- $\mathrm{D}_{28 \mathrm{k}}$ stock solution was prepared by dissolving the lyophilized protein $\left(100 \mu \mathrm{g}\right.$ in $0.1 \mathrm{~mm} \mathrm{CaCl}_{2}$; Swant, Bellinzona, Switzerland) in the standard pipette solution. This stock solution was then diluted with the standard pipette solution to obtain the desired concentration of calbindin- $\mathrm{D}_{28 \mathrm{k}}(10,25,33$, and $66 \mu \mathrm{M})$ that was used for filling the patch pipettes.

Whole-cell recordings were obtained from granule cells in hippocampal slices using the "blind technique" and an SEC-05LX amplifier (standard headstage; NPI Electronics, Tamm, Germany). Series resistance of the cells ranged between 20 and $30 \mathrm{M} \Omega$ and was estimated by bridge balancing after careful compensation of the pipette capacitance.

Immunohistochemistry. Hippocampal slices from rats and mice were fixed overnight in $8 \%$ paraformaldehyde and subsequently resectioned at $40 \mu \mathrm{m}$. Those sections were then incubated for $24 \mathrm{~h}$ at $4^{\circ} \mathrm{C}$ with monoclonal mouse anti-calbindin- $\mathrm{D}_{28 \mathrm{k}}$ antibodies (1:500; Swant) in TBS containing $0.3 \%$ Triton X-100. Next, biotinylated sheep anti-mouse antibodies (1:200; Vector Laboratories, Linaris, Wertheim-Bettingen, Germany) and streptavidin-conjugated Cy5 (1:250; Jackson ImmunoResearch, West Grove, PA) were each applied overnight. A green fluorescent Nissl stain ("Neurotrace"; Molecular Probes, Eugene, OR) was used in some cases for counterstaining. Sections were analyzed with a confocal laser-scanning microscope (Leica TCS NT, equipped with an argonkrypton laser), and images with different dyes (LY and Cy5) were acquired sequentially. For LY, the following filters and laser lines were used: excitation, $488 \mathrm{~nm}$; dichroic, $510 \mathrm{~nm}$; emission bandpass, $530 \pm 30 \mathrm{~nm}$. For Cy5 we used: excitation, $647 \mathrm{~nm}$; dichroic, $660 \mathrm{~nm}$; emission long pass, $665 \mathrm{~nm}$. In separate experiments, we verified (in the absence of Cy5 staining) that LY-filled granule cells do not lead to detectable emission when the Cy5 filter and laser combination was used. All scans were acquired with a $63 \times$ objective (oil, numerical aperture 1.4 ), and the pinhole was set 1 Airy unit. Laser power, detector gain, and offset were adjusted such that in the final scan (two to four averages) only a few pixels had zero or maximal (255) digital units. Typically, detector gain and offset were set to $\sim 70 \%$ and approximately six digital units, respectively.

For calbindin- $\mathrm{D}_{28 \mathrm{k}}$ and doublecortin double-labeling, slices were successively incubated in goat anti-doublecortin antibodies (1:100; Santa
Cruz Biotechnology, Santa Cruz, CA), biotinylated anti-goat antibodies (1:200; Vector Laboratories), and streptavidin-Cy5. Then calbindin- $\mathrm{D}_{28 \mathrm{k}}$ staining was performed as above but developed with a FITC-conjugated anti-mouse antibody (1:200; Serotec, Oxford, UK).

Quantification of immunoreactivity of granule cells. Quantitative image analysis was performed with NIH ImageJ software. The immunofluorescence of a given granule cell, referred to as $F$, was quantified by calculating the mean value over the whole soma and subtracting the background fluorescence. The background fluorescence (the sum of: out of focus light from surrounding granule cells, offset of the photomultiplier, unspecific fluorescence in the tissue, etc.) was determined by measuring the mean fluorescence of small calbindin- $\mathrm{D}_{28 \mathrm{k}}$-negative presumably glial cells (see Fig. $1 B$ ). The small cells were selected within the granule cell layer either in the same scan or in an immediately adjacent scan that was acquired under identical settings.

For quantitative analysis of the gradient of calbindin- $\mathrm{D}_{28 \mathrm{k}}$ immunoreactivity (see Fig. $1 C$ ), we divided the granule cell layer in each scan into 10 sections of $\sim 6 \mu \mathrm{m}$ (see Fig. $1 B$ ). In every section, we calculated the average of the immunofluorescence values $F$ of those parts of the granule cell somata crossing that section. Each of the 10 average values were then normalized on the mean of immunofluorescence values $F$ of all granule cells in that particular scan. This normalization procedure corrects for differences in illumination, focus depth, brightness of staining, and other confounding factors that could be different from slice to slice. The normalized average values were then plotted versus their position within the granule cell layer.

Figure 2 illustrates the time course of the reduction of the immunofluorescence of granule cells during a whole-cell recording. Because granule cells located close to the molecular layer contain more calbindin- $\mathrm{D}_{28 \mathrm{k}}$ than hilar granule cells (compare Fig. 1) we had to compare the immunofluorescence value $F$ of a recorded granule cell with the immunofluorescence of neighboring granule cells in the same section. Therefore, and to correct for the abovementioned confounding factors, $F$ of the recorded cell was normalized on the average of the $F$ values of those granule cells lying in the same section (in analogy to Fig. 1).

When we filled granule cells with different concentrations of purified calbindin- $\mathrm{D}_{28 \mathrm{k}}$ (whole-cell recording time, 30-40 min) we intended to estimate the overall mean calbindin- $\mathrm{D}_{28 \mathrm{k}}$ content of granule cells (see Fig. 4). For this reason the immunofluorescence $F$ of a recorded and filled granule cell was normalized on the mean of the immunofluorescence values $F$ of all granule cells in that particular scan.

To estimate the calbindin- $\mathrm{D}_{28 \mathrm{k}}$ concentration in $\mathrm{CA} 1$ pyramidal cells and CA3 stratum radiatum interneurons (see Fig. 6), calbindin- $D_{28 k}$ staining was developed with Cy2-conjugated streptavidin (1:250; Jackson ImmunoResearch). Then we proceeded as follows in each slice $(n=5): F$ was quantified for dendritic subsegments of the three types of neurons. Next, we calculated the average over all granule cells $\left(F_{\mathrm{av}, \mathrm{gc}}\right)$. Then $F$ of each CA1 pyramidal cell and of each CA3 stratum radiatum interneurons was converted to a calbindin- $\mathrm{D}_{28 \mathrm{k}}$ concentration according to: $33 \mu \mathrm{M}$ ${ }^{\star} F_{\mathrm{CA} 1 / \mathrm{CA} 3} / F_{\mathrm{av}, \mathrm{gc}}$. Finally, the calbindin- $\mathrm{D}_{28 \mathrm{k}}$ concentrations were averaged over all slices for each type of cell. During all scans within one slice detector settings and laser power were kept constant. Laser power was measured by a photodiode, and variations in light intensity were compensated for manually. The calbindin- $\mathrm{D}_{28 \mathrm{k}}$ concentration for mature granule cells shown in Figure 6 was obtained by multiplying the rightmost data point (and the associated error) in Figure $1 C$ with $33 \mu \mathrm{M}$ calbindin- $\mathrm{D}_{28 \mathrm{k}}$.

We tested whether the fluorophore Cy5 accumulates so strongly within granule cells that its emission of fluorescence increases only sublinearly with concentration. We produced a series of streptravidin-Cy5 dilutions that covered the range in which the emission was comparable with that obtain from slices. The streptravidin-Cy5 dilutions contained in microcuvettes were placed under the confocal microscope and were scanned under analogous conditions. We found no signs for saturation of Cy5 emission in this concentration range, and the emission increased proportional to the concentration (data not shown).

Calbindin- $D_{28 k}$ knock-out mice. The calbindin- $\mathrm{D}_{28 \mathrm{k}}$ null mutant mice used in this study have been described previously (Airaksinen et al., 1997). We obtained mice from The Jackson Laboratory (Bar Harbor, 
$\mathrm{ME}$ ), and homozygous knock-out mice were achieved by heterozygous breeding. All animals were genotyped by PCR on DNA samples extracted from tail tissue. The following primers were used: for wild-type, $5^{\prime}$-GCA AGT AAC TAA TGG CAT CG-3' and 5'-TGC AGC GGC TAG TTT GAG AGT G-3'; for null mutant, 5' -ACA TCG CAT CGA GCG AGC AC-3' and 5'-AAG GCG ATG CGC TGC GAA TC-3'.

Numerical simulation of buffered $\mathrm{Ca}^{2+}$ diffusion around a single $\mathrm{Ca}^{2+}$ channel. Numerical simulations were performed to study the buffering of calbindin- $\mathrm{D}_{28 \mathrm{k}}$ on $\mathrm{Ca}^{2+}$ microdomains. We consider a single $\mathrm{Ca}^{2+}$ channel that is embedded in a planar membrane that limits a pseudoinfinitely large hemisphere (radius, $30 \mu \mathrm{m}$ ) around the channel. We are interested in the spatial and temporal development of free $\mathrm{Ca}^{2+}$ around the channel after its opening in the presence and absence of various buffers. We make the following standard assumptions: Fickian diffusion of calbindin- $\mathrm{D}_{28 \mathrm{k}}$ and of $\mathrm{Ca}^{2+}$ and second order reaction of calbindin- $\mathrm{D}_{28 \mathrm{k}}$ with $\mathrm{Ca}^{2+}$ according to the law of mass action. We further assume that the diffusion coefficient of calbindin- $\mathrm{D}_{28 \mathrm{k}}$ does not change when it binds $\mathrm{Ca}^{2+}$. These assumptions lead to a well known set of differential equations that can be found previously (Nowycky and Pinter, 1993; Roberts, 1994; Naraghi and Neher, 1997). The diffusion coefficient, $K_{\mathrm{D}}$, and $k_{\text {on }}$ of calbindin- $\mathrm{D}_{28 \mathrm{k}}$ were $20 \mu \mathrm{m}^{2} / \mathrm{s}, 700 \mathrm{nM}, 2.7 \times$ $10^{7} \mathrm{M}^{-1} \mathrm{~s}^{-1}$, respectively (Nägerl et al., 2000; Berggard et al., 2002; Schmidt et al., 2003). A $40 \mu \mathrm{m}$ concentration of calbindin- $\mathrm{D}_{28 \mathrm{k}}$ was modeled as $160 \mu \mathrm{M} \mathrm{Ca}^{2+}$-binding sites with identical $\mathrm{Ca}^{2+}$ association rates and affinities that were derived as averages of the corresponding values of the four $\mathrm{Ca}^{2+}$-binding sites recently published. The hemisphere (radius $30 \mu \mathrm{m}$ ) was divided into 30,000 shells. Within the first $600 \mathrm{~nm}$ from the origin, the shell size was constant at $0.06 \mathrm{~nm}$, and the size of the following shells increased by $5 \%$ successively. The maximum single-channel $\mathrm{Ca}^{2+}$ current (at physiological levels of divalent cations) was assumed to be 0.2 pA (Gollasch et al., 1992). Because we are interested in $\mathrm{Ca}^{2+}$ microdomains that develop during action potentials, we took into account the varying driving force of the single-channel current during the repolarizing phase of the action potential. Thus, the single-channel current is not square-like: the channel opens and closes in a step-like manner, but the current steeply increases during the open time and reaches a value of 0.2 $\mathrm{pA}$ at the end of the opening. The time course of single-channel current amplitude was empirically approximated with the following function (in picoamperes $): 0.2^{*}\left(1+\tanh \left(5^{*}(t-0.2)\right)\right) / 2$, where $t(\mathrm{~ms})$ is the time (see Fig. $5 A$, inset). Simulation starts at $t=0 \mathrm{~ms}$ where the channel opens, ends at $1.6 \mathrm{~ms}$, and the channel closes abruptly at $t=0.8 \mathrm{~ms}$. Before the simulation starts, calbindin- $\mathrm{D}_{28 \mathrm{k}}$ and $\mathrm{Ca}^{2+}$ are homogenously distributed and have reached chemical equilibrium at resting $\mathrm{Ca}^{2+}$ concentration ( $50 \mathrm{~nm}$ ). The differential equations were integrated using CalC (Calcium Calculator) software [version 4.9.8, freeware by V. Matveev et al. (2004), http://web.njit.edu/ matveev/calc.html]. This script-operated program uses the Crank-Nicholson differences scheme (onedimensional) and an adaptive time-step method to maintain a given level of accuracy $(<0.1 \%)$. Because CalC only offers the full spherical geometry, we increased the single-channel current by factor 2 , which yields results identical to simulating a hemisphere because of the complete symmetry. The correctness of the program was thoroughly checked against the transient analytical solutions of unbuffered $\mathrm{Ca}^{2+}$ diffusion and of buffered $\mathrm{Ca}^{2+}$ diffusion in case of a very mobile buffer (Crank, 1975; Pape et al., 1998). The output of the program was imported into IgorPro for additional analysis and for graphing.

Formulas. $\mathrm{Ca}^{2+}$-free buffer concentration was calculated according to the law of mass action

$$
[\text { buffer }]_{\text {free }}=\frac{[\text { buffer }]_{\text {total }} \times K_{\mathrm{D}, \text { buffer }}}{K_{\text {D,buffer }}+\left[\mathrm{Ca}^{2+}\right]_{\text {rest }}}
$$

$\mathrm{Ca}^{2+}$-binding ratio was calculated as (Neher, 1995):

$$
\kappa_{\mathrm{Cb}}=\frac{[\mathrm{Cb}] \times K_{\mathrm{D}, \mathrm{Cb}}}{\left(K_{\mathrm{D}, \mathrm{Cb}}+\left[\mathrm{Ca}^{2+}\right]_{\mathrm{rest}}\right)^{2}} .
$$

Influence of calbindin- $D_{28 k}$ on global $\mathrm{Ca}^{2+}$ signals. Under the assumptions of the single compartment model (Neher, 1998), the buffering effect of calbindin- $\mathrm{D}_{28 \mathrm{k}}$ on the initial amplitude $(A)$ and on the decay time constant $(\tau)$ of free $\mathrm{Ca}^{2+}$ after brief $\mathrm{Ca}^{2+}$ influx can be described by the following equations (cf. Helmchen et al., 1996). Let $\kappa_{\mathrm{Cb}}$ be the $\mathrm{Ca}^{2+}$ binding ratio of calbindin- $\mathrm{D}_{28 \mathrm{k}}$ and $\kappa_{\mathrm{X}}$ that of other endogenous $\mathrm{Ca}^{2+}$ buffers. Then, one can write for the amplitude and decay of free $\mathrm{Ca}^{2+}$ :

$$
A_{\mathrm{Cb}}=A \frac{\kappa_{\mathrm{X}}+1}{\kappa_{\mathrm{X}}+\kappa_{\mathrm{Cb}}+1}, \quad \tau_{\mathrm{Cb}}=\tau \frac{\kappa_{\mathrm{X}}+\kappa_{\mathrm{Cb}}+1}{\kappa_{\mathrm{X}}+1},
$$

where $\tau$ and $A$ denote the values of the amplitude and the decay time constant of free $\mathrm{Ca}^{2+}$ in the absence of calbindin- $\mathrm{D}_{28 \mathrm{k}}$.

Data are given as mean \pm SEM throughout. The level of statistical significance was set to $\alpha=0.05$.

\section{Results}

The distribution of calbindin- $\mathrm{D}_{28 \mathrm{k}}$ immunoreactivity observed in rat hippocampal slices using confocal laser-scanning microscopy was comparable with that described previously (Baimbridge and Miller, 1982; Sloviter, 1989). All granule cells were intensely labeled throughout their entire cytoplasm including dendrites, somata, and axons (Fig. $1 \mathrm{~A}$ ). In contrast, CA3 pyramidal cells remained completely unstained (Fig. $1 A$ ), and only $\sim 50 \%$ of CA1 pyramidal cells were labeled by the antibody (data not shown). An identical staining pattern was observed in slices obtained from mice, but this staining was completely absent in slices from calbindin- $\mathrm{D}_{28 \mathrm{k}}(-/-)$ mice $(n=4$; data not shown).

After closer inspection of the immunoreactivity of granule cells, we found a gradient of the fluorescence intensity within the granule cell layer indicating a heterogeneity of the intracellular calbindin- $\mathrm{D}_{28 \mathrm{k}}$ concentration: granule cells at the hilar border appeared significantly less bright than granule cells adjacent to the molecular layer (Figs. $1 B, 2 A-D$ ). The fluorescence intensity of granule cell somata ranged from $58 \pm 3 \%$ at the hilar border to $122 \pm 4 \%$ at the outer edge of the cell layer when compared with the overall average fluorescence of all granule cells in each scan $(n=10)$ (Fig. 1C) (see Materials and Methods for details).

It is well established that new granule cells are generated throughout postnatal life (van Praag et al., 2002) and that those cells appear first at the border to the hilus and later integrate into outer parts of the granular layer (Cameron et al., 1993). Newborn granule cells do not contain calbindin- $\mathrm{D}_{28 \mathrm{k}}$ (Rami et al., 1987). To test whether the gradient of calbindin- $\mathrm{D}_{28 \mathrm{k}}$ content reflects successive maturation of granule cells after their generation, we performed a double staining for calbindin- $\mathrm{D}_{28 \mathrm{k}}$ and a marker of newly generated granule cells in adult hippocampus, doublecortin (Brown et al., 2003). Indeed, we observed an overlap of calbindin- $\mathrm{D}_{28 \mathrm{k}}$ and doublecortin labeling supporting this hypothesis (Fig. $1 D$ ). Numerous weakly calbindin- $\mathrm{D}_{28 \mathrm{k}}$-positive cells displayed doublecortin-positive filaments in their cytoplasm (small arrows). On the contrary, strongly calbindin- $\mathrm{D}_{28 \mathrm{k}}$-positive cells were doublecortin-negative. Notably, cells prominently marked with doublecortin antibodies, morphologically resembling the earliest postmitotic neuroblast stage with horizontally oriented processes (large arrowheads), were virtually calbindin- $\mathrm{D}_{28 \mathrm{k}}$-negative.

Considering that calbindin- $\mathrm{D}_{28 \mathrm{k}}$ is present in all compartments of granule cells, it is likely that this protein is a mobile cytoplasmic $\mathrm{Ca}^{2+}$ buffer. To test the intracellular mobility of calbindin- $\mathrm{D}_{28 \mathrm{k}}$, we performed whole-cell recordings of granule cells in hippocampal slices. During whole-cell recordings, there is a direct connection between the interior of the patch pipette and the cytoplasm of the recorded cell such that molecules up to a molecular weight of 150,000 show diffusional equilibration between the pipette and the cytoplasm (Pusch and Neher, 1988). In this experiment, the pipette solution contained no 


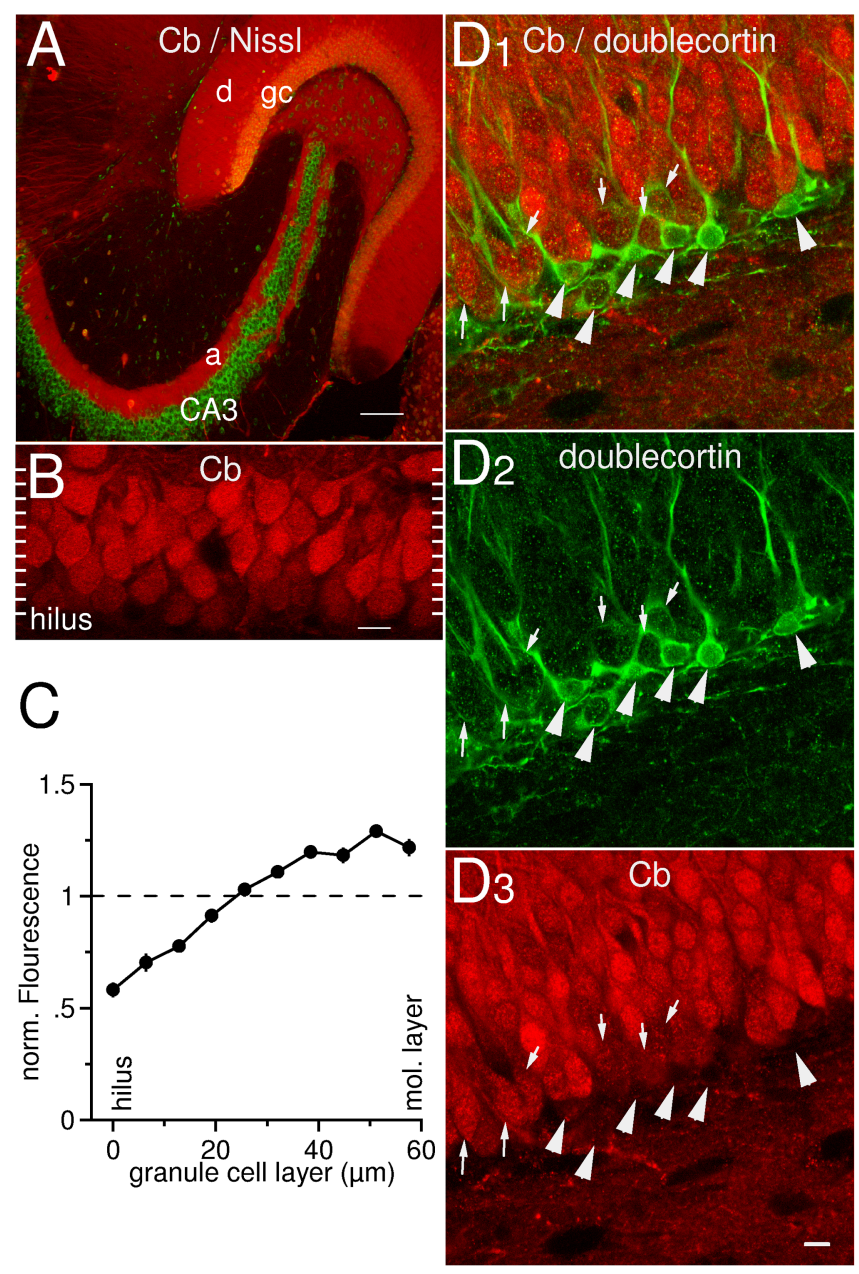

Figure 1. Distribution of calbindin- $D_{28 \mathrm{k}}$ immunoreactivity in the dentate area. $A$, Dual channel scan obtained with a confocal laser microscope. Calbindin- $\mathrm{D}_{28 \mathrm{k}}(\mathrm{Cb})$ is present throughout the entire cytoplasm of granule cells: dendrites (d), somata ( $\mathrm{gc}$ ), and axons (a) are stained (red). Note that CA3 pyramidal cells are completely negative, whereas some scattered interneurons are found positive. Green indicates fluorescent counterstain ("Nissl"). Scale bar, $100 \mu \mathrm{m}$. $10 \times$ objective. $B$, High-magnification scan of the granule cell layer stained for calbindin- $D_{28 \mathrm{k}}$. Note that the calbindin- $D_{28 k}$ content of granule cells is heterogeneous: granule cells adjacent to the molecular layer (top) are brighter than hilar dentate granule cells (bottom). The white ticks on the sides of the image indicate how the scan was divided into 10 sections for quantitative analysis in C (see Materials and Methods for details). C, Quantitative analysis of the gradient of calbindin- $D_{28 k}$ immunoreactivity across the granule cell layer. The granule cell layer $(n=10)$ was divided into 10 sections, and the normalized mean fluorescence in each section is plotted versus its position within the layer. D, Double-labeling with anti-calbindin- $D_{28 \mathrm{k}}$ (red) and antidoublecortin antibodies (green). Cells that are weakly calbindin- $\mathrm{D}_{28 \mathrm{k}}$-labeled are doublecortinpositive (small arrows). Strongly calbindin- $D_{28 k}$-positive cells are doublecortin-negative. Note that cells intensely stained for doublecortin appear calbindin- $D_{28 \mathrm{k}}$-negative (large arrowheads).

calbindin- $\mathrm{D}_{28 \mathrm{k}}$. Because the volume of the pipette solution $(>20$ $\mu \mathrm{l})$ exceeds that of the cytoplasm $(<20 \mathrm{pl})$ by several orders of magnitude, there should be a strong dilution ("washout") of calbindin- $\mathrm{D}_{28 \mathrm{k}}$ during the course of a whole-cell recording. Indeed, when slices were fixed and stained after prolonged wholecell recordings, granule cells displayed only very weak calbindin- $\mathrm{D}_{28 \mathrm{k}}$ immunoreactivity (Fig. $2 \mathrm{D}$ ). In contrast, when the patch pipette was withdrawn from the cell after a short recording period of $30 \mathrm{~s}$, calbindin- $\mathrm{D}_{28 \mathrm{k}}$ immunoreactivity was comparable with that of the neighboring cells (Fig. 2 A). To estimate the time course of the washout of calbindin- $\mathrm{D}_{28 \mathrm{k}}$, we systematically varied the recording time by withdrawing the patch pipette (Fig. $2 A-D$ ). Figure $2 E$ summarizes the measured fluorescence obtained from 34 whole-cell recordings of different durations. It is evident that the immunoreactivity of the recorded cells decreases with increasing whole-cell recording periods. Fitting an exponential function to the data suggests that calbindin- $\mathrm{D}_{28 \mathrm{k}}$ washes out of granule cell somata with a time constant of $\sim 10 \mathrm{~min}$ (Fig. $2 \mathrm{E}$ ).

The experiments so far show that the intracellular calbindin- $\mathrm{D}_{28 \mathrm{k}}$ concentration can be controlled via the solution in the patch pipette provided that there is sufficient time for diffusional equilibration. The idea of the next series of experiments was to supplement purified calbindin- $\mathrm{D}_{28 \mathrm{k}}$ to the pipette solution to find the concentration of calbindin- $\mathrm{D}_{28 \mathrm{k}}$ that is needed to restore the immunoreactivity of the recorded cell. To ensure comparable diffusional equilibration, cells were recorded for a period of $30-40 \mathrm{~min}$. Increasing the calbindin- $\mathrm{D}_{28 \mathrm{k}}$ concentration in the patch pipette to 25,33 , and $66 \mu \mathrm{M}$ caused a corresponding increase in the fluorescence intensity of the recorded cell (Fig. 3). Cells filled with $66 \mu \mathrm{M}$ are clearly brighter than surrounding granule cells. A plot of the normalized calbindin- $\mathrm{D}_{28 \mathrm{k}}$ immunofluorescence of filled granule cells (see Materials and Methods) versus the concentration of calbindin- $\mathrm{D}_{28 \mathrm{k}}$ in the patch pipette is depicted for 24 granule cells in Figure 4. From this calibration curve, the mean endogenous concentration of calbindin- $\mathrm{D}_{28 \mathrm{k}}$ over all granule cells was estimated to be $\sim 33 \mu \mathrm{M}$ (Fig. 4 , arrowhead). Using data from Figure 1, we calculate that mature granule cells close to the molecular layer enclose $\sim 40 \mu \mathrm{M}$ and that newborn granule cells at the hilar border contain $\sim 18 \mu \mathrm{M}$ calbindin- $\mathrm{D}_{28 \mathrm{k}}$.

Knowing the concentration and the $\mathrm{Ca}^{2+}$ affinity (Veenstra et al., 1997; Berggard et al., 2002), it is possible to predict how calbindin- $\mathrm{D}_{28 \mathrm{k}}$ will affect spatially homogenous $\mathrm{Ca}^{2+}$ elevations as they occur in dendritic segments and in nerve terminals (see Discussion). However, it is less straightforward to estimate the buffering effect of calbindin- $\mathrm{D}_{28 \mathrm{k}}$ on very localized, submicroscopic $\mathrm{Ca}^{2+}$ signals $\left(\mathrm{Ca}^{2+}\right.$ microdomains). $\mathrm{Ca}^{2+}$ microdomains are steep $\mathrm{Ca}^{2+}$ concentration gradients around a $\mathrm{Ca}^{2+}$ channel (or channels) that build up very rapidly after opening of the channel and reach values in the high micromolar range. $\mathrm{Ca}^{2+}$ microdomains have been implicated in the release of neurotransmitter and in the activation of $\mathrm{Ca}^{2+}$-sensitive potassium channels. Because on this spatial scale $\mathrm{Ca}^{2+}$ ions diffuse some distance before they are captured by the buffer [capture time $_{\text {calbindin-D28k }}=\left([\text { buffer }]_{\text {free }} \times k_{\text {on }}\right)^{-1}=248 \mu \mathrm{s}$; Eq. $1, k_{\text {on }}=$ $\left.2.8 \times 10^{7} \mathrm{M}^{-1} \mathrm{~s}^{-1}\right]$, there is a region around the channel $(<200$ $\mathrm{nm}$ ) where chemical equilibrium is not achieved among $\mathrm{Ca}^{2+}$ and buffers. We used numerical simulations to explore how strong $40 \mu \mathrm{M}$ calbindin- $\mathrm{D}_{28 \mathrm{k}}$ reduces the increment of free $\mathrm{Ca}^{2+}$ around $\mathrm{C} \mathrm{Ca}^{2+}$ channel in that nonequilibrium domain (see Materials and Methods for details). We depict a physiologically realistic scenario where a $\mathrm{Ca}^{2+}$ channel opens around the peak of an action potential and remains open for $0.8 \mathrm{~ms}$ (Fig. $5 A$, inset). When calbindin- $\mathrm{D}_{28 \mathrm{k}}$ is added, the maximal free $\mathrm{Ca}^{2+}$ concentration reached during the channel opening is hardly diminished close to the $\mathrm{Ca}^{2+}$ source at $15 \mathrm{~nm}$ (Fig. $5 \mathrm{~A}$, black dashed line). Only farther away from the channel at a distance of $150 \mathrm{~nm}$ (red dashed line) does calbindin- $\mathrm{D}_{28 \mathrm{k}}$ cause a notable reduction in free $\mathrm{Ca}^{2+}$ (Fig. 5A). A more pronounced inhibitory effect of the buffer is observed after closure of the channel. This is best seen in the right panel of Figure $5 A$ where traces are replotted on a semilogarithmic scale (see black arrow). In the absence of buffers, $\mathrm{Ca}^{2+}$ needs $\sim 5 \mathrm{~ms}$ to return to resting levels, whereas in the presence of calbindin- $\mathrm{D}_{28 \mathrm{k}}$, resting levels are restored within 
$\sim 600 \mu$ s (Fig. $5 A$, right). Figure $5 B$ summarizes the distance-dependent inhibition of free $\mathrm{Ca}^{2+}$ at the end of the channel open time (black lines) and the distanceindependent acceleration of the decay of free $\mathrm{Ca}^{2+}$ after closure of the channel (red lines). To evaluate the robustness of the results, we have modified different parameters of the simulation. We varied $k_{\text {on }}$ (colored groups of lines), from an extreme lower limit of $0.6 \times$ $10^{7}$ to an upper limit of $5.6 \times 10^{7} \mathrm{M}^{-1} \mathrm{~s}^{-1}$ (Nägerl et al., 2000), as well as the singlechannel current amplitude (indicated by different line modes) to explore clustering of $10-30 \mathrm{Ca}^{2+}$ channels (Fig. 5C). The buffering effect of calbindin- $\mathrm{D}_{28 \mathrm{k}}$ was consistent even when high single-channel current amplitudes were simulated. As expected, the extent of inhibition was sensitive to alterations of $k_{\text {on }}$ : an upper limit of the inhibition of $\Delta \mathrm{Ca}^{2+}$ by calbindin- $\mathrm{D}_{28 \mathrm{k}}$ at $150-200 \mathrm{~nm}$ is $\sim 50 \%$, and a lower limit at that distance is $\sim 10 \%$, which is reached when extremely low EGTA-like values for $k_{\text {on }}$ are used.

Next, we tested whether other types of hippocampal neurons contain levels of calbindin- $\mathrm{D}_{28 \mathrm{k}}$ similar to that seen for granule cells. For this purpose, we compared the immunofluorescence of CA1 pyramidal cells and CA3 stratum radiatum interneurons with that of granule cells $(n=60)$ in the same slice (five slices) acquired under identical conditions (see Materials and Methods for details). In high-magnification confocal laser scans, we quantified the intensity of dendritic segments that have approximately the same geometry among the three different cell types (Fig. $6 A$ ). In this way, we estimated that CA1 pyramidal cells and CA3 stratum radiatum interneurons contain on average $45 \pm 2 \mu \mathrm{M}(n=59)$ and $47 \pm 6 \mu \mathrm{M}(n=22)$ calbindin- $\mathrm{D}_{28 \mathrm{k}}$, respectively.

\section{Discussion}

Calbindin- $\mathrm{D}_{28 \mathrm{k}}$ is mobile and reaches $40 \mu \mathrm{M}$ in hippocampal neurons

Our experiments indicate that cellular calbindin- $\mathrm{D}_{28 \mathrm{k}}$ freely exchanges with the solution in the patch pipette. The calbindin- $\mathrm{D}_{28 \mathrm{k}}$ content of granule cells decreases during wholecell recordings with a time constant of $\sim 10 \mathrm{~min}$ (Fig. 2). Taking into account that granule cells possess a large dendritic tree ( $\sim 200 \mu \mathrm{m}$; compare Fig. 1 ), from which calbindin- $\mathrm{D}_{28 \mathrm{k}}$ initially can be replenished by diffusion into the soma, this time constant well matches the value expected for free diffusional equilibration of a $28 \mathrm{kDa}$ protein under our conditions (Pusch and Neher, 1988).

The fact that the cellular calbindin- $\mathrm{D}_{28 \mathrm{k}}$ concentration equilibrates with that of the patch pipette enabled us to load single granule cells with defined concentrations of purified calbindin- $\mathrm{D}_{28 \mathrm{k}}$. We estimated the endogenous calbindin- $\mathrm{D}_{28 \mathrm{k}}$ concentration to be $40 \mu \mathrm{M}$ in mature granule cells by testing which concentration of purified calbindin- $\mathrm{D}_{28 \mathrm{k}}$ mimics the immunofluorescence of neighboring, untouched granule cells (Figs.
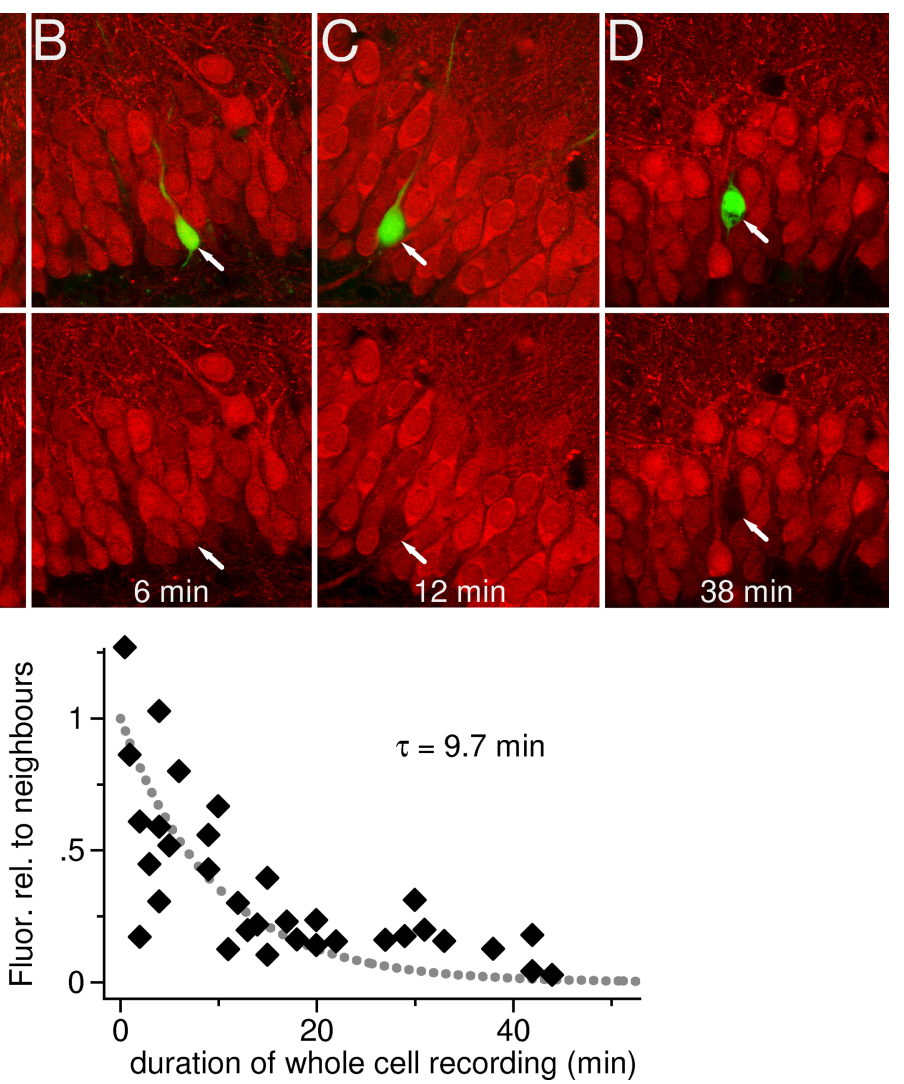

Figure 2. Endogenous calbindin- $D_{28 \mathrm{k}}$ is diluted during whole-cell recordings of granule cells. $A$, A granule cell was recorded and filled with $L Y$ for 30 s in whole-cell mode. Subsequently, the slice was fixed and stained for calbindin- $D_{28 \mathrm{k}}$. Top, Confocal scans of $L Y$ fluorescence

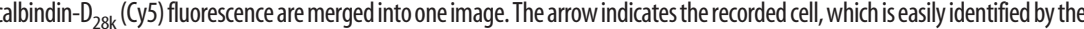
列 recorded cell is visible, signifying a dilution of endogenous calbindin- $D_{28 k}$ concentration. The cell is less bright than its neighbors but still than background levels when compared with calbindin- $D_{28 \mathrm{k}}$-negative cells in the molecular layer or in the hilus (in between granule cell is similar to background levels when compared with calbindin- $D_{28 \mathrm{k}}$-negative cells in the molecular layer or in the hilus (in between positive mossy fibers), indicating that the cellular calbindin- $D_{28 \mathrm{k}}$ content is nearly completely lost. $E$, Quantification of the loss of calbindin- $\mathrm{D}_{28 \mathrm{k}}$ immunoreactivity during whole-cell recordings. The immunofluorescence of each recorded granule cell was normalized on neighboring granule cells (fluorescence relationship to neighbors; see Materials and Methods for details) and plotted versus the whole-cell recording time $(n=34)$. The time-dependent drop in immunofluorescence could be fitted with an exponential function yielding a time constant of $\sim 10 \mathrm{~min}$.

3, 4). This procedure should be readily applicable to quantify the intracellular concentration of other low-abundance soluble proteins in different types of cells.

The concentration of calbindin- $\mathrm{D}_{28 \mathrm{k}}$ in newly generated granule cells was estimated by double labeling with antibodies against doublecortin and calbindin- $\mathrm{D}_{28 \mathrm{k}}$. Newly generated granule cells transiently express doublecortin for 2-3 weeks after they have entered the postmitotic stage (Brown et al., 2003). We found a gradient of doublecortin immunoreactivity opposite to that of calbindin- $\mathrm{D}_{28 \mathrm{k}}$ : neuroblasts at the hilar border were strongly positive for doublecortin but virtually negative for calbindin- $\mathrm{D}_{28 \mathrm{k}}$. On average, doublecortin-immunoreactive cells displayed a lower calbindin- $\mathrm{D}_{28 \mathrm{k}}$ content $(0-20 \mu \mathrm{M})$ compared with mature granule cells. Because strongly calbindin- $\mathrm{D}_{28 \mathrm{k}}$-labeled granule cells were found to be doublecortin-negative, it appears that granule cells need $\sim 2-3$ weeks to increase their endogenous $\mathrm{Ca}^{2+}$ buffer content to mature levels. It has been reported that newborn granule cells show enhanced $\mathrm{Ca}^{2+}$-dependent synaptic plasticity because of immature membrane properties (Schmidt- 

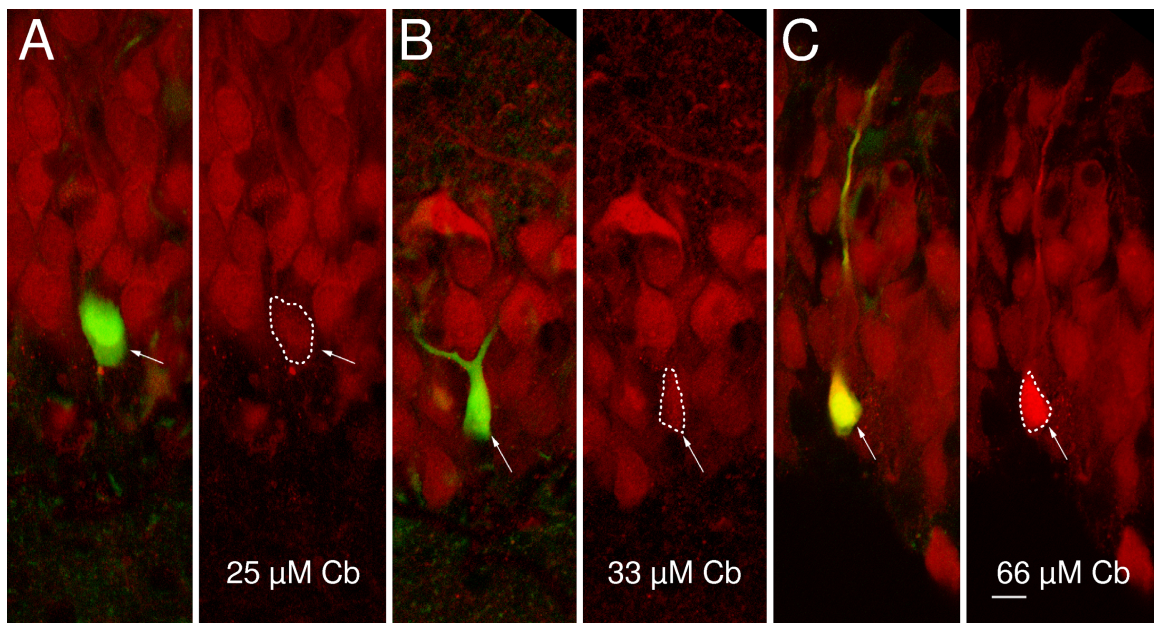

when investigated within the first 2 postnatal weeks. At these early stages the cellular calbindin- $\mathrm{D}_{28 \mathrm{k}}$ content has not yet fully developed (Tortosa and Ferrer, 1994; Yoon et al., 2000), and $\mathrm{Ca}^{2+}$ signaling might significantly differ from the adult pattern.

The virtually complete exchange of calbindin- $\mathrm{D}_{28 \mathrm{k}}$ between the patch pipette and the cell interior provides strong evidence that most of calbindin- $\mathrm{D}_{28 \mathrm{k}}$ in neurons constitutes a mobile $\mathrm{Ca}^{2+}$ buffer. The diffusional mobility is an important buffer property, as outlined above, and also is crucial for microfluorometric imaging studies investigating cellular $\mathrm{Ca}^{2+}$ signaling using ion-sensitive dyes. Those dyes are frequently loaded into the cell via the patch pipette solution, and this procedure typically requires whole-cell recordings of $>30 \mathrm{~min}$. Considering the rapid washout of calbindin- $\mathrm{D}_{28 \mathrm{k}}$, such imaging studies potentially underestimate the endogenous $\mathrm{Ca}^{2+}$-binding capacity profoundly. Furthermore, $\mathrm{Ca}^{2+}$-dependent processes such as induction of synaptic plasticity or the occurrence and propagation of $\mathrm{Ca}^{2+}$ waves could be strongly altered by washout of cellular $\mathrm{Ca}^{2+}$ buffers. A brief bolus loading with a high indicator concentra-

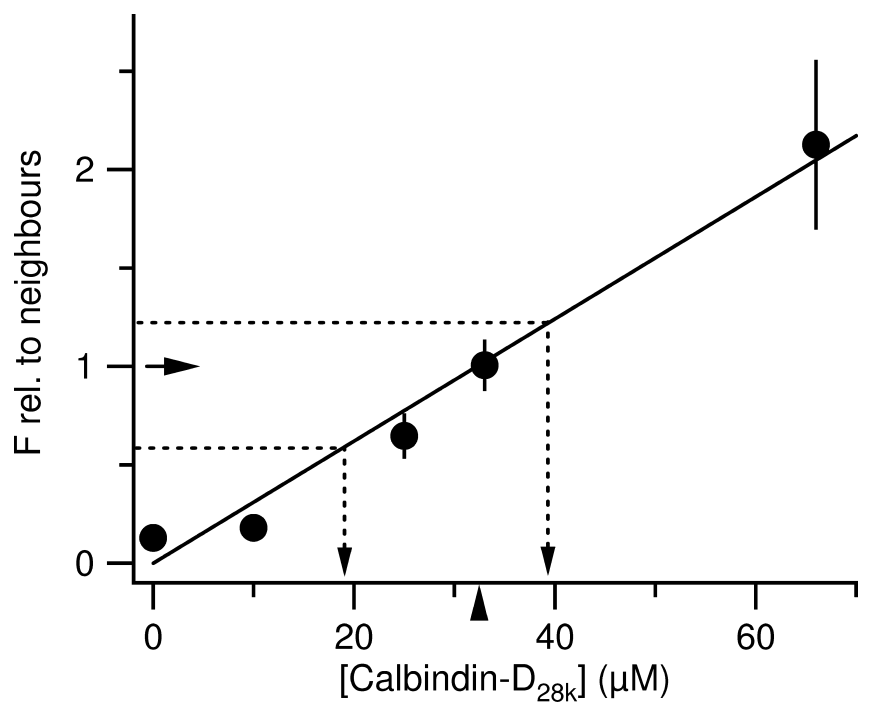

Figure 4. Granule cells contain $33 \mu \mathrm{m}$ calbindin- $\mathrm{D}_{28 \mathrm{k}}$. Quantitative analysis of 26 experiments as shown in Figure 3. Dentate granule cells were loaded with $0 \mu \mathrm{M}(n=3), 10 \mu \mathrm{M}$ $(n=6), 25 \mu \mathrm{M}(n=7), 33 \mu \mathrm{M}(n=7)$, or $66 \mu \mathrm{M}(n=3)$ calbindin- $\mathrm{D}_{28 \mathrm{k}}$. The immunofluorescence of the recorded cell was normalized on the mean fluorescence of all neighboring granule cells, averaged for each concentration, and then plotted versus the concentration. Data points were fitted by a line (superimposed). From this line, the calbindin- $D_{28 k}$ concentration that lets the recorded cells appear equifluorescent to surrounding granule cells (normalized fluorescence equals 1; arrow) can be obtained: $32.5 \mu \mathrm{m}$ (denoted by the arrowhead). The dashed lines originating from the ordinate illustrate translations of immunofluorescence of granule cells (as determined in Fig. 1) into calbindin- $\mathrm{D}_{28 \mathrm{k}}$ concentrations.

Hieber et al., 2004). In light of our findings, it seems possible that the very weak $\mathrm{Ca}^{2+}$ buffer capacity of young granule cells additionally facilitates the induction of synaptic plasticity. Similar considerations also apply to granule cells and CA1 pyramidal cells tion could reduce the dilution effect and disclose the role of endogenous buffers in shaping $\mathrm{Ca}^{2+}$ signals. However, when aiming to measure cellular $\mathrm{Ca}^{2+}$ buffering quantitatively, additional efforts have to be made to obtain an approximation of the resulting dye concentration (cf. Helmchen et al., 1996).

\section{Calbindin- $\mathrm{D}_{28 \mathrm{k}}$ and global $\mathrm{Ca}^{2+}$ signals}

The quantitative determination of the intracellular concentration of calbindin- $\mathrm{D}_{28 \mathrm{k}}$ allows theoretical predictions of how this $\mathrm{Ca}^{2+}$ buffer will affect different types of intracellular $\mathrm{Ca}^{2+}$ signals. The influence of buffers on (small) global $\mathrm{Ca}^{2+}$ signals caused by brief $\mathrm{Ca}^{2+}$ entry as they typically occur in dendritic compartments or in synaptic terminals is well described by the single compartment model (Neher and Augustine, 1992). In this model, the key parameter regarding the action of the buffer is the $\mathrm{Ca}^{2+}$-binding ratio, $\kappa$, which is the ratio of the change in buffer-bound $\mathrm{Ca}^{2+}$ over the change in free $\mathrm{Ca}^{2+}(\delta[\mathrm{Ca} \mathrm{Bf}] / \delta[\mathrm{Ca}])$. Given that calbindin- $\mathrm{D}_{28 \mathrm{k}}$ displays a $\mathrm{Ca}^{2+}$ affinity of $700 \mathrm{nM}$ (Berggard et al., 2002) and assuming a resting $\mathrm{Ca}^{2+}$ concentration of $50 \mathrm{nM}$, it follows that $40 \mu \mathrm{M}$ calbindin- $\mathrm{D}_{28 \mathrm{k}}\left(=160 \mu \mathrm{M} \mathrm{Ca}{ }^{2+}\right.$-binding sites) provides a $\kappa_{\mathrm{Cb}}$ of $\sim 200$ (Eq. 2 ). Thus, only $\sim 0.5 \%$ of entering $\mathrm{Ca}^{2+}$ ions appear as free ions, whereas the rest will be bound to buffer molecules. As a result, the initial amplitude of a rise in free $\mathrm{Ca}^{2+}$ will be significantly decreased because $\mathrm{Ca}^{2+}$ is bound by calbindin- $\mathrm{D}_{28 \mathrm{k}}$. Subsequently, the decay of free $\mathrm{Ca}^{2+}$ will be slowed because the bound ions are not available for removal by extrusion mechanisms. If we assume that endogenous $\mathrm{Ca}^{2+}$ buffers other than calbindin- $\mathrm{D}_{28 \mathrm{k}}$ constitute a $\mathrm{Ca}^{2+}$ binding ratio $\left(\kappa_{\mathrm{X}}\right)$ of $\sim 50$ (Neher, 1995$)$, then calbindin- $\mathrm{D}_{28 \mathrm{k}}$ should decrease the amplitude of $\mathrm{Ca}^{2+}$ transients and slow their decay as much as fivefold (Eq. 3).

A recent imaging study used $\mathrm{Ca}^{2+}$-sensitive dyes to investigate endogenous $\mathrm{Ca}^{2+}$ buffers in axon terminals of granule cells. 

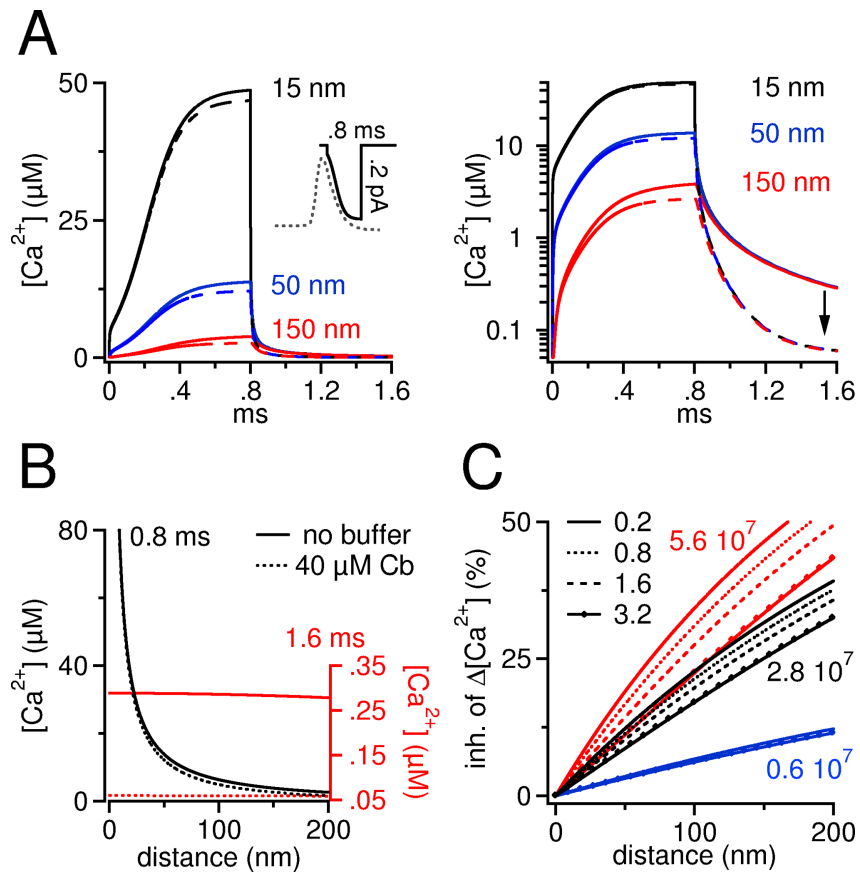

Figure 5. Numerical simulation of buffered $\mathrm{Ca}^{2+}$ diffusion around a single $\mathrm{Ca}^{2+}$ channel. $A$, Left, Time course of free $\mathrm{Ca}^{2+}$ after opening and closing of a single $\mathrm{Ca}^{2+}$ channel in the absence and presence of calbindin- $D_{28 k}$ at three distances from the channel $(15,50$, and 150 $\mathrm{nm})$. The channel opens at $0 \mathrm{~ms}$ and closes at $0.8 \mathrm{~ms}$. The inset shows the time-dependent variation of the simulated single-channel current according to the varying driving force during repolarization of the action potential. For comparison, an action potential is aligned on the same time scale (gray dotted trace). Calbindin- $\mathrm{D}_{28 \mathrm{k}}$ exerts a distance-dependent inhibition on free $\mathrm{Ca}^{2+}$. A notable percentage reduction of free $\mathrm{Ca}^{2+}$ is observed only at a distance of $150 \mathrm{~nm}$. In contrast, calbindin- $\mathrm{D}_{28 \mathrm{k}}$ strongly reduces free $\mathrm{Ca}^{2+}$ after closure of the channel. This is best seen in the right panel, where data are plotted on a semilogarithmic graph. The arrow indicates the prominent reduction in $\mathrm{Ca}^{2+}$ when the channel has closed. The single-channel open time chosen here signifies an upper limit, because most $\mathrm{Ca}^{2+}$ channels would close earlier (Lee and Elmslie, 1999) during the repolarization phase of an action potential. $B$, Radial gradient of action potential associated free $\mathrm{Ca}^{2+}$ reached around the channel after $0.8 \mathrm{~ms}$ (black lines) and after $1.6 \mathrm{~ms}$ (when the channel is closed for $0.8 \mathrm{~ms}$, red lines). The continuous lines denote the $\mathrm{Ca}^{2+}$ profile in the absence of calbindin- $D_{28 \mathrm{k}}(\mathrm{Cb})$; the dashed lines denote the $\mathrm{Ca}^{2+}$ profile in the presence of calbindin- $\mathrm{D}_{28 \mathrm{k}}$. Black lines, A steep $\mathrm{Ca}^{2+}$ gradient is present that reaches $>80 \mu \mathrm{m}$ close to the channel. It can be seen that close to the channel $(<30 \mathrm{~nm})$, the black line and the black dotted line superimpose, indicating that free $\mathrm{Ca}^{2+}$ is hardly affected by calbindin- $\mathrm{D}_{28 \mathrm{k}}$. Red lines, The $\mathrm{Ca}^{2+}$ gradient has collapsed, and a residual $\mathrm{Ca}^{2+}$ concentration is effectively removed at all distances through shuttling by calbindin- $\mathrm{D}_{28 \mathrm{k}} \cdot \mathrm{Ca}^{2+}$ concentration for red lines is indicated by the right axis, which is scaled up for clarity. Note that the resting $\mathrm{Ca}^{2+}$ concentration $(50 \mathrm{~nm})$ of the left and the right axis are on the same level. Distance indicates the distance from the $\mathrm{Ca}^{2+}$ source. $C$, Radial gradients of the percentage inhibition of the increase in $\mathrm{Ca}^{2+}$ above resting $\mathrm{Ca}^{2+}\left(\Delta\left[\mathrm{Ca}^{2+}\right]\right)$ caused by calbindin- $\mathrm{D}_{28 \mathrm{k}}$ at the end of a 0.8 -ms-long channel opening. For each condition, we ran the simulation for $0.8 \mathrm{~ms}$ and calculated a radial profile of the percentage inhibition of $\Delta \mathrm{Ca}^{2+}$ at the end of the channel opening as shown by black lines in $B$. Three different families of curves are plotted (red, black, and blue) that represent three different values of $k_{\text {on }}$ (indicated by small numbers, in $\mathrm{M}^{-1} \mathrm{~s}^{-1}$ ). Within each of the three families, we varied the single-channel current amplitude as coded by the mode of the lines $(0.2,0.8,1.6$, and $3.2 \mathrm{pA}$; see key). At $15 \mathrm{~nm}$, the concentration of $\mathrm{Ca}^{2+}$-bound calbindin- $\mathrm{D}_{28 \mathrm{k}}$ increased at $0.8 \mathrm{~ms}$ by $\sim 8 \mu \mathrm{M}(0.2 \mathrm{pA})$ and by $\sim 100 \mu \mathrm{M}(3.2 \mathrm{pA})$. It should be noted that the percentage inhibition plotted here represents an upper estimate, because no other competing buffer is included in the model. If, for example, a $500 \mu \mathrm{m}$ concentration of a fixed buffer with a relatively fast on-rate $\left(k_{\text {on }}=1 \times 10^{8} \mathrm{~m} / \mathrm{s} ; K_{\mathrm{D}}=50 \mu \mathrm{m}\right)$ is present, then the inhibition caused by addition of calbindin- $D_{28 \mathrm{k}}$ will be reduced by a factor of 2 .

The total endogenous $\mathrm{Ca}^{2+}$ buffers could be well described mathematically assuming a $130 \mu \mathrm{M}$ concentration of a single buffer species with a high $\mathrm{Ca}^{2+}$ affinity $(\sim 500 \mathrm{nM}$ ) (Jackson and Redman, 2003). No attempts have been made to reveal the number or the molecular identity of the underlying buffers. In
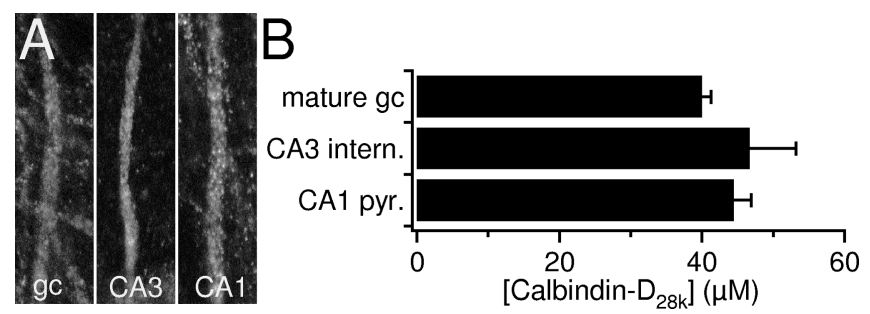

Figure 6. Different types of hippocampal neurons contain similar calbindin- $D_{28 \mathrm{k}}$ concentrations. A, High-magnification scans of dendrites of a granule cell ( $\mathrm{gc}$ ), a CA3 interneuron, and a CA1 pyramidal cell as they were used for quantitative analysis. Note that dendritic segments chosen have comparable geometry and are equally bright. Image dimensions are $13 \times 34 \mu \mathrm{m}$. $B$, Summary bar graph of intracellular calbindin- $D_{28 \mathrm{k}}$ concentrations in hippocampal neurons as determined by comparing their calbindin- $\mathrm{D}_{28 \mathrm{k}}$-related immunofluorescence. All three types of cells investigated contain similar concentrations around $40 \mu \mathrm{m}$. For details of calculations, see Materials and Methods.

light of our findings $\left(160 \mu \mathrm{M}\right.$ mobile $\mathrm{Ca}^{2+}$-binding sites of calbindin- $\mathrm{D}_{28 \mathrm{k}}$ ) and considering that there are probably additional low-affinity $\mathrm{Ca}^{2+}$-binding sites present in granule cells, it appears likely that Jackson and Redman (2003) still underestimated the total $\mathrm{Ca}^{2+}$-binding capacity of granule cells. Using microfluorometric imaging techniques, $\kappa_{\mathrm{S}}$ of CA1 pyramidal cell dendrites was determined to be $\sim 190$ (Helmchen et al., 1996). This value is close to our estimate of the $\kappa_{\mathrm{S}}$ mediated by calbindin- $\mathrm{D}_{28 \mathrm{k}}$ in CA1 pyramidal cells. However, as argued above, the undisturbed $\kappa_{\mathrm{S}}$ of CA1 pyramidal cells could be even higher.

\section{Calbindin- $\mathrm{D}_{28 \mathrm{k}}$ and $\mathrm{Ca}^{2+}$ microdomains}

The influence of calbindin- $\mathrm{D}_{28 \mathrm{k}}$ on highly localized $\mathrm{Ca}^{2+}$ signals that are beyond the resolution of current imaging techniques was assessed by numerical simulations. Having identified the intracellular concentration of calbindin- $\mathrm{D}_{28 \mathrm{k}}$, simulations could be performed with relatively high accuracy because the $\mathrm{Ca}^{2+}$ binding properties and the diffusion coefficient of calbindin- $\mathrm{D}_{28 \mathrm{k}}$ have been determined (Nägerl et al., 2000; Berggard et al., 2002; Schmidt et al., 2003). Calbindin- $\mathrm{D}_{28 \mathrm{k}}$ exerts two main actions on microdomains caused by single or by clustered $\mathrm{Ca}^{2+}$ channels. First there is a distance-dependent inhibition of the increase in free $\mathrm{Ca}^{2+}$. Calbindin- $\mathrm{D}_{28 \mathrm{k}}$ is ineffective close to the $\mathrm{Ca}^{2+}$ source $(<30 \mathrm{~nm})$ but inhibits the increase in free $\mathrm{Ca}^{2+}$ at $200 \mathrm{~nm}$ by $\sim 35 \%$. In effect, calbindin- $\mathrm{D}_{28 \mathrm{k}}$ reduces the spatial extent of a $\mathrm{Ca}^{2+}$ microdomain to $\sim 200-400 \mathrm{~nm}$ without affecting its amplitude at the origin. The second result is that calbindin- $\mathrm{D}_{28 \mathrm{k}}$ greatly speeds up the temporal collapse of the microdomain at all distances after closure of the $\mathrm{Ca}^{2+}$ channel or channels. If, for example, $\sim 30$ tightly clustered $\mathrm{Ca}^{2+}$ channels close after an action potential, $\mathrm{Ca}^{2+}$ influx stops abruptly, but a residual increase in free $\mathrm{Ca}^{2+}$ of $\sim 6 \mu \mathrm{M}$ persists for several milliseconds in the absence of calbindin- $\mathrm{D}_{28 \mathrm{k}}$. If mobile calbindin- $\mathrm{D}_{28 \mathrm{k}}$ is added, this $\mathrm{Ca}^{2+}$ is effectively shuttled away, and free $\mathrm{Ca}^{2+}$ drops below $\sim 200 \mathrm{~nm}$ within $\sim 0.6 \mathrm{~ms}$. Thus, calbindin- $\mathrm{D}_{28 \mathrm{k}}$ sharpens $\mathrm{Ca}^{2+}$ microdomains in space and time and thereby enables a more precise discrimination of the site and the time course of $\mathrm{Ca}^{2+}$ influx by downstream effectors.

Because of their high $\mathrm{Ca}^{2+}$ affinity, the $\mathrm{Ca}^{2+}$-binding sites of calbindin- $\mathrm{D}_{28 \mathrm{k}}$ can be saturated after sufficiently large $\mathrm{Ca}^{2+}$ influx. It has been reasoned that saturation of endogenous $\mathrm{Ca}^{2+}$ buffers can cause a facilitation of neurotransmitter release $(\mathrm{Ne}-$ her, 1998). A requirement for this process is that the unsaturated $\mathrm{Ca}^{2+}$ buffer is able to capture some $\mathrm{Ca}^{2+}$ ions before they reach 
the $\mathrm{Ca}^{2+}$ sensor of the release machinery. Release will then be facilitated when previous activity depletes some $\mathrm{Ca}^{2+}$-binding sites such that more $\mathrm{Ca}^{2+}$ reaches the $\mathrm{Ca}^{2+}$ sensor. Indeed, it was suggested recently that paired-pulse facilitation $(200 \%$ at $100 \mathrm{~ms}$ intervals) at the mossy fiber-CA3 synapse apparently results from saturation of calbindin- $\mathrm{D}_{28 \mathrm{k}}$ (Blatow et al., 2003; but see Mori-Kawakami et al., 2003). However, given that mossy fiber terminals contain $40 \mu \mathrm{M}$ calbindin- $\mathrm{D}_{28 \mathrm{k}}$, it seems unlikely that calbindin- $\mathrm{D}_{28 \mathrm{k}}$ contributes to paired-pulse facilitation by saturation under their conditions (Matveev et al., 2004). First, this would imply that $\mathrm{Ca}^{2+}$ sensors and $\mathrm{Ca}^{2+}$ channels are more loosely associated than previously thought. In fact, calbindin- $\mathrm{D}_{28 \mathrm{k}}$ reduces $\mathrm{Ca}^{2+}$ microdomains by the required extent ( $\sim 20 \%$ ) only at a mean distance of $\geq 100 \mathrm{~nm}$. Second, saturation of calbindin- $\mathrm{D}_{28 \mathrm{k}}$ can at most be partial $(<25 \%)$, because during a single action potential, the total $\mathrm{Ca}^{2+}$ concentration does not increase by more than $\sim 40 \mu \mathrm{M}$ (Bischofberger et al., 2002; Jackson and Redman, 2003). Third, within the interstimulus interval used ( $100 \mathrm{~ms}), \mathrm{Ca}^{2+}$ nearly completely decays back to baseline levels (Vogt and Regehr, 2001; Dietrich et al., 2003; Jackson and Redman, 2003). Instead of acting via buffer saturation, calbindin- $\mathrm{D}_{28 \mathrm{k}}$ might play a direct regulatory role in paired-pulse facilitation at this synapse.

\section{References}

Airaksinen MS, Eilers J, Garaschuk O, Thoenen H, Konnerth A, Meyer M (1997) Ataxia and altered dendritic calcium signaling in mice carrying a targeted null mutation of the calbindin $\mathrm{D}_{28 \mathrm{k}}$ gene. Proc Natl Acad Sci USA 94:1488-1493.

Baimbridge KG, Miller JJ (1982) Immunohistochemical localization of calcium-binding protein in the cerebellum, hippocampal formation and olfactory bulb of the rat. Brain Res 245:223-229.

Baimbridge KG, Miller JJ, Parkes CO (1982) Calcium-binding protein distribution in the rat brain. Brain Res 239:519-525.

Baimbridge KG, Celio MR, Rogers JH (1992) Calcium-binding proteins in the nervous system. Trends Neurosci 15:303-308.

Berggard T, Miron S, Onnerfjord P, Thulin E, Akerfeldt KS, Enghild JJ, Akke $\mathrm{M}$, Linse S (2002) Calbindin $\mathrm{D}_{28 \mathrm{k}}$ exhibits properties characteristic of a $\mathrm{Ca}^{2+}$ sensor. J Biol Chem 277:16662-16672.

Bischofberger J, Geiger JR, Jonas P (2002) Timing and efficacy of $\mathrm{Ca}^{2+}$ channel activation in hippocampal mossy fiber boutons. J Neurosci 22:10593-10602.

Blatow M, Caputi A, Burnashev N, Monyer H, Rozov A (2003) $\mathrm{Ca}^{2+}$ buffer saturation underlies paired pulse facilitation in calbindin- $\mathrm{D}_{28 \mathrm{k}}$ containing terminals. Neuron 38:79-88.

Brown JP, Couillard-Despres S, Cooper-Kuhn CM, Winkler J, Aigner L, Kuhn HG (2003) Transient expression of doublecortin during adult neurogenesis. J Comp Neurol 467:1-10.

Cameron HA, Woolley CS, McEwen BS, Gould E (1993) Differentiation of newly born neurons and glia in the dentate gyrus of the adult rat. Neuroscience 56:337-344

Crank J (1975) The Mathematics of diffusion. Oxford: Oxford UP.

Dietrich D, Kirschstein T, Kukley M, Pereverzev A, von der Brèlie C, Schneider T, Beck H (2003) Functional specialization of presynaptic Cav2.3 $\mathrm{Ca}^{2+}$ channels. Neuron 39:483-496.

Gabso M, Neher E, Spira ME (1997) Low mobility of the $\mathrm{Ca}^{2+}$ buffers in axons of cultured Aplysia neurons. Neuron 18:473-481.

Gollasch M, Hescheler J, Quayle JM, Patlak JB, Nelson MT (1992) Single calcium channel currents of arterial smooth muscle at physiological calcium concentrations. Am J Physiol 263:C948-C952.

Helmchen F, Imoto K, Sakmann B (1996) $\mathrm{Ca}^{2+}$ buffering and action potential-evoked $\mathrm{Ca}^{2+}$ signaling in dendrites of pyramidal neurons. Biophys J 70:1069-1081.

Jackson MB, Redman SJ (2003) Calcium dynamics, buffering, and buffer saturation in the boutons of dentate granule-cell axons in the hilus. J Neurosci 23:1612-1621.

Lee HK, Elmslie KS (1999) Gating of single N-type calcium channels recorded from bullfrog sympathetic neurons. J Gen Physiol 113:111-124.

Maeda H, Ellis-Davies GC, Ito K, Miyashita Y, Kasai H (1999) Supralinear $\mathrm{Ca}^{2+}$ signaling by cooperative and mobile $\mathrm{Ca}^{2+}$ buffering in Purkinje neurons. Neuron 24:989-1002.

Matveev V, Zucker RS, Sherman A (2004) Facilitation through buffer saturation: constraints on endogenous buffering properties. Biophys J 86:2691-2709.

Mori-Kawakami F, Kobayashi K, Takahashi T (2003) Developmental decrease in synaptic facilitation at the mouse hippocampal mossy fiber synapse. J Physiol (Lond) 553:37-48.

Nägerl UV, Novo D, Mody I, Vergara JL (2000) Binding kinetics of calbindin- $\mathrm{D}_{28 \mathrm{k}}$ determined by flash photolysis of caged $\mathrm{Ca}^{(2+)}$. Biophys J 79:3009-3018.

Naraghi M, Neher E (1997) Linearized buffered $\mathrm{Ca}^{2+}$ diffusion in microdomains and its implications for calculation of $\left[\mathrm{Ca}^{2+}\right]$ at the mouth of a calcium channel. J Neurosci 17:6961-6973.

Neher E (1995) The use of fura-2 for estimating Ca buffers and Ca fluxes. Neuropharmacology 34:1423-1442.

Neher E (1998) Usefulness and limitations of linear approximations to the understanding of $\mathrm{Ca}^{2+}$ signals. Cell Calcium 24:345-357.

Neher E, Augustine GJ (1992) Calcium gradients and buffers in bovine chromaffin cells. J Physiol (Lond) 450:273-301.

Nowycky MC, Pinter MJ (1993) Time courses of calcium and calciumbound buffers following calcium influx in a model cell. Biophys $\mathrm{J}$ 64:77-91.

Pape PC, Jong DS, Chandler WK (1998) Effects of partial sarcoplasmic reticulum calcium depletion on calcium release in frog cut muscle fibers equilibrated with 20 mM EGTA. J Gen Physiol 112:263-295.

Pusch M, Neher E (1988) Rates of diffusional exchange between small cells and a measuring patch pipette. Pflügers Arch 411:204-211.

Rami A, Brehier A, Thomasset M, Rabie A (1987) Cholecalcin (28-kDa calcium-binding protein) in the rat hippocampus: development in normal animals and in altered thyroid states. An immunocytochemical study. Dev Biol 124:228-238.

Roberts WM (1994) Localization of calcium signals by a mobile calcium buffer in frog saccular hair cells. J Neurosci 14:3246-3262.

Schmidt H, Brown EB, Schwaller B, Eilers J (2003) Diffusional mobility of parvalbumin in spiny dendrites of cerebellar purkinje neurons quantified by fluorescence recovery after photobleaching. Biophys J 84:2599-2608.

Schmidt-Hieber C, Jonas P, Bischofberger J (2004) Enhanced synaptic plasticity in newly generated granule cells of the adult hippocampus. Nature 429:184-187.

Sloviter RS (1989) Calcium-binding protein (calbindin- $\mathrm{D}_{28 \mathrm{k}}$ ) and parvalbumin immunocytochemistry: localization in the rat hippocampus with specific reference to the selective vulnerability of hippocampal neurons to seizure activity. J Comp Neurol 280:183-196.

Tortosa A, Ferrer I (1994) Poor correlation between delayed neuronal death induced by transient forebrain ischemia, and immunoreactivity for parvalbumin and calbindin $\mathrm{D}_{28 \mathrm{k}}$ in developing gerbil hippocampus. Acta Neuropathol (Berl) 88:67-74.

van Praag H, Schinder AF, Christie BR, Toni N, Palmer TD, Gage FH (2002) Functional neurogenesis in the adult hippocampus. Nature 415:1030-1034.

Veenstra TD, Johnson KL, Tomlinson AJ, Naylor S, Kumar R (1997) Determination of calcium-binding sites in rat brain calbindin $\mathrm{D}_{28 \mathrm{k}}$ by electrospray ionization mass spectrometry. Biochemistry 36:3535-3542.

Vogt KE, Regehr WG (2001) Cholinergic modulation of excitatory synaptic transmission in the CA3 area of the hippocampus. J Neurosci 21:75-83.

Yoon SP, Chung YY, Chang IY, Kim JJ, Moon JS, Kim HS (2000) Postnatal development of parvalbumin and calbindin $\mathrm{D}_{28 \mathrm{k}}$ immunoreactivities in the canine hippocampus. J Chem Neuroanat 19:143-154. 